\title{
DNA Hybridization-Based Differential Peptide Display Identified Potential Osteogenic Peptides
}

\author{
Wataru Hatakeyama ${ }^{1,2} \cdot$ Cliff Lee $^{1} \cdot$ John Da Silva ${ }^{3} \cdot$ David M. Kim $^{1} \cdot$ Shigemi Nagai $^{1} \cdot$ Hisatomo Kondo $^{2}$. \\ Masazumi Nagai ${ }^{1}$ (1)
}

Accepted: 6 November 2020 / Published online: 23 November 2020

(C) The Author(s) 2020

\begin{abstract}
A DNA hybridization-based differential peptide display (DPD) was developed for the screening of phage peptide library to find osteogenic peptides intended to bind to epigenetically induced osteogenic receptors on NIH/3T3 (3T3) cell surface. In the presence of DNA methylation inhibitor of 5-azacytidine (5AZC), an osteoblastic receptor of bone morphogenetic protein (BMP) receptor 1A (BMPR1A) was induced on the cell surface of NIH/3T3 fibroblasts. Cyclic heptamer-displaying phage library was screened against vehicle and 5AZC treated (Tx) 3T3 cells. Antisense oligo against library against library peptide coding DNA of control 3T3 cell bound phages were synthesized to subtract common binders from that of 5AZC-Tx 3T3 cell-bound phages that included 5AZC-induced receptor binders. The library peptide coding regions of conformational receptor binder-subtracted DPD were PCR-amplified and cloned into a plasmid vector specifically designed for short peptide expression. No unique binder was identified when 96 clones were randomly picked from the third round of panning against 5AZC-treated $3 \mathrm{~T} 3$ cells, suggesting miscellaneous bindings to cell surface proteins. Unique binders showing homology to known function proteins were successfully identified when constitutive receptor binders were subtracted from 5AZC-induced protein binders. Some of identified peptides significantly increased alkaline phosphatase activity in 5AZC-Tx 3T3 cells. DPD can be a useful tool to screen functional peptide bindings to cell surface receptors.
\end{abstract}

Extended author information available on the last page of the article 


\section{Graphic Abstract}
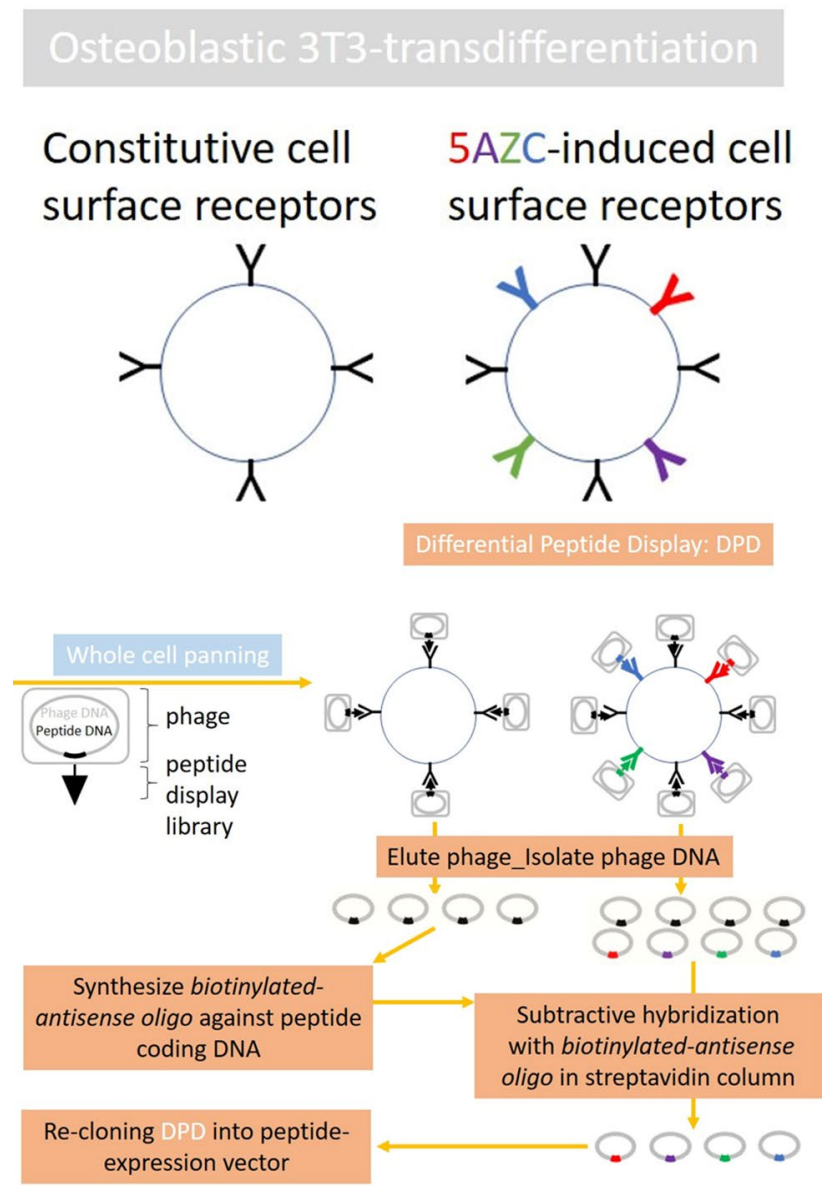

Keywords Osteogenic peptide $\cdot$ Phage display $\cdot$ Whole cell panning $\cdot$ Differential subtraction $\cdot$ DNA hybridization

\section{Introduction}

Iliac crest autogenous bone grafts have long served as the gold standard for the restoration of large bone defects, such as in surgical excision sites of bone metastatic tumors and alveolar cleft palate and traumatic bone loss (Giannoudis and Dinopoulos 2005). However, donor site morbidity and complications due to graft harvesting are common, including postoperative and chronic pain, infection, pelvic instability, scar formation and contour defects, and nerve injury and sensory disturbances (Kalk et al. 1996; Banwart et al. 1995; Myeroff and Archdeacon 2011; Canady et al. 1993). Although autogenous bone is well regarded for its self-healing abilities and has high success in treatment, its use is limited by the amount of autograft that can be obtained, as well shaping the graft in complex defects (Salgado et al. 2004). Alternatives to autologous bone grafts include allograft bone, metal, and ceramic plates/implants and scaffolds, including custom 3D printing or milling of the bone substitutes to precisely fit the shape of the osseous defect (Salgado et al. 2004; Ma et al. 2017). An ideal scaffold provides not only a matrix for cell proliferation and bone growth, but also contains osteoinductive properties or even osteogenic potential, often through the application of growth factors.

Recent efforts in increasing the osteogenic potential of tissue engineering combined the use of both growth factors and epigenetics to produce osteoblast formation. Specifically, Cho et al. (2017) induced epigenetic modification of fibroblasts with 5-aza-2'-deoxycytidine (5-AZC) which activated the transcription of osteogenic genes via demethylation, and subsequent treatment with bone morphogenetic protein 2 (BMP-2) induced the transdifferentiation of the modified fibroblasts into osteoblasts. Because of the abundance in connective tissue, fibroblasts could be a great candidate to be recruited to regenerate host bone. However, using BMP2 in clinical application has many limitations, including production cost, degradation in immobilization chemistry, and a short biological half-life (Schmidmaier 
et al. 2007). With such a potent molecule, the effects are difficult to control, and significant inflammation/edema is present in almost all cases. Serious adverse events can occur, such as ectopic bone formation, nerve injury, edema with risk of airway obstruction, and even reports of increased cancer risk (Tannoury and An 2014). On the other hand, the active moiety of a protein ligands can be represented by a short peptide, such as newly discovered cryptides (Ueki et al. 2007). It is possible that a peptide be produced that can induce transdifferentiation of the modified fibroblasts without the unwanted side effects of BMP2. Peptides can be chemically synthesized, and such xeno-free material is not only less infectious, but also highly resistant to chemical modifications for the extension of biological half-life and stable coupling to a scaffold (deGruyter et al. 2017). In order to have efficacy in vivo, a therapeutic peptide needs to bind cell surface conformational proteins. Whole cell panning is an ideal tool to identify such conformational binder peptides. Successful application of whole cell panning requires effective subtraction of irrelevant bindings to constitutively expressed miscellaneous cell surface proteins. Conventional subtraction is done by pre-clearing of phage peptide library with control cells, i.e. 5AZC-untreated 3T3 cells in our study. The main drawback of pre-clearing is possible disposal of potential peptides. Although stringent washing in pre-clearing subtraction reduces this risk, irrelevant binders will remain in the screening library. As inspired by the differential display (Liang and Pardee 1992), we focused on the single strands of M13 phage DNA of PhD-C7C phage display library. Although there is no complementarity between peptide sequences, therefore, control $3 \mathrm{~T} 3$ cellbinder peptides were not able to be directly subtracted from 5AZC-treated 3T3 cell-binder peptides, peptide-encoding single strand DNAs were able to be subtracted with the corresponding complementary bases. The present study introduces "DNA hybridization-based Differential Peptide Display (DPD)" to extract 5AZC-induced cell surface binders from parental cell surface binders. The significant novelty of DPD is to display comprehensive peptide binders to unknown cell surface receptors that are induced by physiological, pathological and therapeutic alteration. This study, DPD was applied to screen peptide binders to 5ACZ-induced cell surface receptors in 3T3 fibroblasts showing osteoblastic phenotypes.

\section{Materials and Methods}

\section{Induction of Osteoblastic Transdifferentiation of Fibroblasts}

NIH/3T3 fibroblasts (3T3 cells) were maintained in Dulbecco's Modified Eagle Medium (DMEM) supplemented with $10 \%$ fetal bovine serum (FBS). For the induction of osteblastic transdifferentiation, 3T3 cells at $70 \%$ in initial confluency in 12-well plate were treated with $5 \mathrm{AZC}$ at 1 , 3.3 and $10 \mu \mathrm{g} / \mathrm{mL}$ and vehicle for $24 \mathrm{~h}$. Expression of BMP receptor 1A (BMPR1A) was analyzed by western blot and flow cytometry by using a primary antibody (MA5-17,036, clone 4B7B2, Thermo Fisher Scientific, USA), and secondary antibodies of anti-mouse IgG of HRP-conjugate (Western blot) and PE-conjugate (FACS) (Jackson ImmunoResearch, USA).

\section{Screening of 3T3 Cell Surface Binder Peptide}

The schematic workflow of the DPD was drawn in the graphical abstract. Briefly, DPD was composed of 3 steps: (1) whole cell panning against control and 5AZC-Tx 3T3 cells; (2) purification of DNA from control and 5AZC-Tx 3T3 binder phages, and subtraction probe preparation from the control binder DNA; (3) DNA-hybridization based Differential Peptide Display (DPD).

\section{Whole Cell Panning}

Peptide library (PhD-C7C, New England Biolabs: NEB, MA, USA) was screened for the binding in control and 5AZC-Tx 3T3 cell surface by whole cell panning. All following procedures obeyed the manufacturer's instruction with adaptive modification for DPD. Briefly, each treatment of cells was washed with PBS and panned with $1 \times 10^{11} \mathrm{cfu}$ of the peptide-displaying phages (100 representations of each peptide clone) in $1 \mathrm{~mL}$ of PBS-2\% FBS at $4{ }^{\circ} \mathrm{C}$ for $1 \mathrm{~h}$ with gentle rocking. Unbound phages were washed off with ice cold PBS-2\% FBS. Bound phages were eluted with $100 \mathrm{mM}$ glycine, $0.5 \mathrm{M} \mathrm{NaCl}, \mathrm{pH} 2.2,0.1 \%$ Triton X100 and neutralized with $1 \mathrm{M}$ Tris base ( $\mathrm{pH}$ 9.1). Phages were amplified and diluted to $1 \times 10^{11} \mathrm{cfu}$ in $1 \mathrm{~mL}$ of PBS-2\% FBS for the next round of panning. Panning was repeated another two times.

\section{Preparation of Subtraction Probe}

Single stranded-sense DNA (ssDNA) was purified from $1 \times 10^{13} \mathrm{cfu}$ of phages from $3 \mathrm{rd}$ round panning in control $3 \mathrm{~T} 3$ cells with a spin column kit (Genomic DNA Clean and Concentrator $^{\mathrm{TM}}$, Zymo Research, CA, USA). One microgram of purified ssDNA was mixed with $20 \mathrm{nmol}$ each of 5 '-end biotinylated-reverse primer (5'-biot-CTCCACCGCA) and extension blocking peptide (5'-ddTCAAGCAGAGTG AGppp-3'; dd; dideoxy, ppp: triphosphate) in $1 \mathrm{~mL}-$ reaction buffer containing $2.5 \mu \mathrm{M}$ of each dNTP in $20 \mathrm{mM}$ Tris-HCl, $\mathrm{pH} 7.5,5 \mathrm{mM} \mathrm{MgCl}_{2}$ and $0.5 \mathrm{mM}$ DTT. Figure 1a illustrates the targeting region of subtraction probe. The reaction mixture was heat denatured at $95{ }^{\circ} \mathrm{C}$ for $10 \mathrm{~min}$ and rapidly 


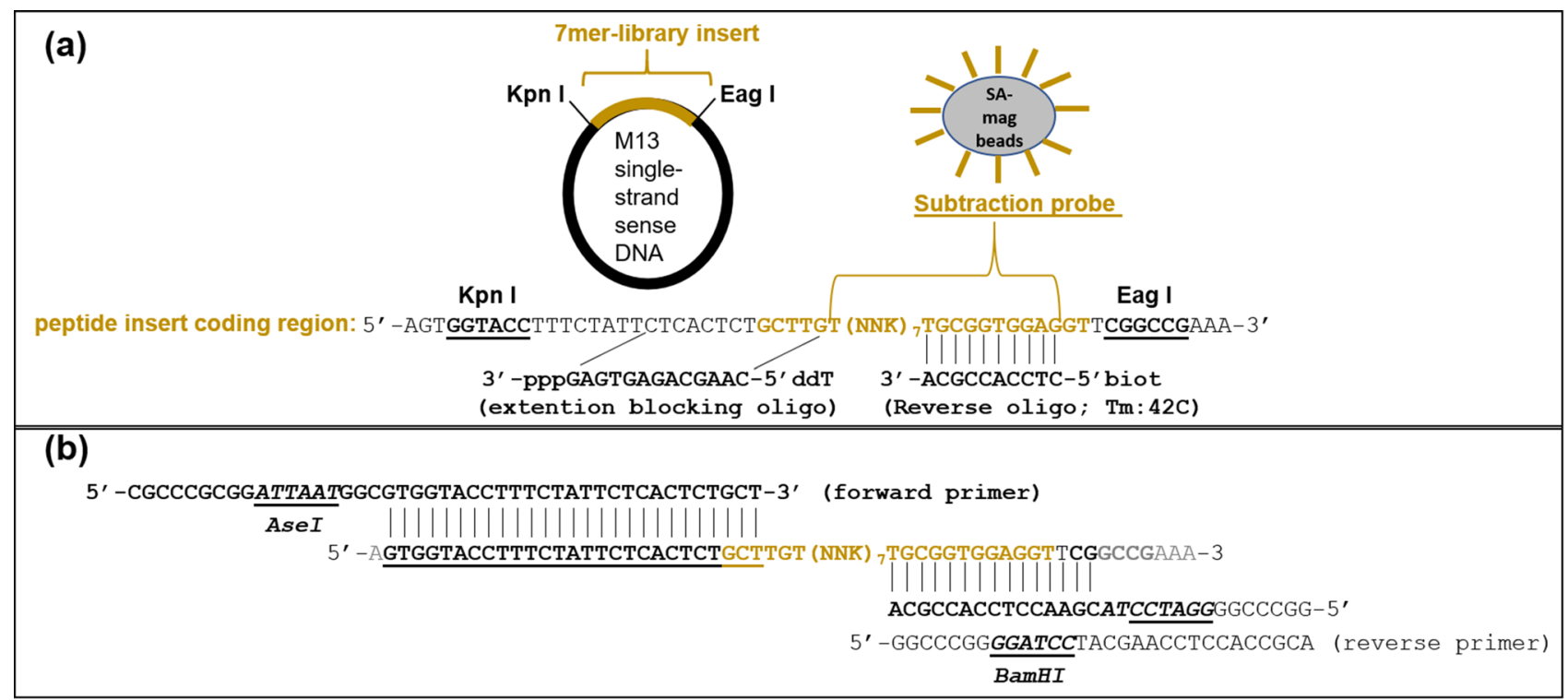

Fig. 1 DNA Oligo probes and primers. a Biotinylated reverse oligo annealed at 3 '-region of library peptide coding region of phage DNA and extended to the 5 '-coding region until blocking oligo by klenow

cooled down to $37^{\circ} \mathrm{C}$. Antisense strand DNA oligo (As oligo) synthesis was carried out with eight units of klenow fragment of DNA polymerase (New England Biolabs, MA, USA) at $37^{\circ} \mathrm{C}$ for $1 \mathrm{~h}$. The resultant biotinylated As oligos, which included common 3'-end cloning site sequence (5'CTCCACCGCA) and 7 mer library peptide-specific $(\mathrm{NNK})_{7}$, were heat denatured at $95{ }^{\circ} \mathrm{C}$ and captured with $500 \mu \mathrm{g}$ of streptavidin-magnet beads (SA-mag beads, NEB, MA, USA). The SA-mag beads captured As oligos were used to subtract constitutively expressed control 3T3-binder phages from the 5AZC-Tx unique binders in the following DPD.

\section{DNA-Subtraction Based Differential Peptide Display (DPD)}

Single stranded-sense DNA (ssDNA) was purified from $1 \times 10^{12}$ cfu of 5AZC-Tx 3 T3 binder phages by the spin column and suspended in $1 \mathrm{~mL}$ of hybridization buffer composed of $20 \mathrm{mM}$ Tris pH 8.0, $20 \mathrm{mM} \mathrm{MgCl} 2,150 \mathrm{mM}$ $\mathrm{NaCl}, 0.02 \%$ Tween-20, and $1 \mathrm{mg} / \mathrm{ml}$ bovine Serum albumin (BSA). Purified phage ssDNA was then hybridized with the previously prepared antisense subtraction oligos. Hybridization was first denatured at $94^{\circ} \mathrm{C}$ for $3 \mathrm{~min}$, then incubated at $67{ }^{\circ} \mathrm{C}$ in a heated water bath for $30 \mathrm{~min}$ for negative selection. Hybridized subtraction complexes were removed with SA-mag beads by using a neodymium magnet. Unbound ssDNA in the supernatant, which enriched 5AZC-Tx unique binders, were transferred to new tube, and concentrated in $10 \mu \mathrm{L}$ of elution buffer by using the spin column. Prehyridized original 5ACZ-Tx binder phage ssDNA was also prepared as the pre-DPD control.
DNA polymerase. b PCR primer set targeted PhD-C7C-library peptide coding region to produce pPEPTIDE vector-compatible overlaps of Ase I and BamHI

\section{Cloning to Peptide Expression Vector}

The concentrated pre- and post-DPD DNA was PCRamplified with a primer set to produce $\mathrm{PhD}-\mathrm{C} 7 \mathrm{C}$-coding fragment for cloning into pPEPTIDE vector (MoBi Tec, Goettingen, Germany). 5'-CGCCCGCGGATTAATGGC GTGGTACCTTTCTATTCTCACTCTGCT-3' and 5'-GGC CCGGGGATCCTACGAACCTCCACCGCA were used as forward and reverse primers, respectively. The two primers were designed to produce the vector-compatible overlaps of AseI and BamHI as illustrated in Fig. 1b. The first three cycles of 3-step PCR were performed at $94{ }^{\circ} \mathrm{C}$ for $30 \mathrm{~s}$, $63{ }^{\circ} \mathrm{C}$ for $30 \mathrm{~s}$, and $72{ }^{\circ} \mathrm{C}$ for $30 \mathrm{~s}$ followed by additional 20 cycles of 2 -step at $94{ }^{\circ} \mathrm{C}$ for $30 \mathrm{~s}$ and $72{ }^{\circ} \mathrm{C}$ for $30 \mathrm{~s}$. PCR fragments were cleaved with AseI and BamHI, purified with a kit (Edge Biosystems QuickStep2 PCR Purification Kit, Thermo Fisher Scientific, USA), and ligated with the linearized AseI_BamHI expression vector in the pPEPTIDE vector kit. The ligation mix was transformed into $E$. coli XL-1 Blue competent cells (Thermo Fisher Scientific, USA) and cloned colonies on LB-ampicillin plate. Ninety-six colonies from vehicle control and 5AZC-DPD derived plasmids were randomly picked and mini-prepped for sequencing (Genewiz, USA).

\section{Preparative Expression and Purification of DPD Peptides for Alkaline Phosphatase Activity}

The cloned vectors were transformed into the expression host of competent BL21 (DE3) for the expression 
and purification according to the manufacturer's instruction. Purified peptides were quantified with a peptide assay kit (Pierce Quantitative Colorimetric Peptide Assay, Thermo Fisher Scientific, USA). For alkaline phosphatase activity, 3T3 cells were previously treated with 5AZC at $10 \mu \mathrm{M}$ for $24 \mathrm{~h}$ in osteogenic medium supplemented with $\beta$-glycerophosphate $(5 \mathrm{mM})$ and ascorbic acid $(50 \mu \mathrm{g} / \mathrm{mL})$. Peptide was added at $1 \mu \mathrm{g} / \mathrm{mL}$ to osteogenic medium in the absence of 5AZC. Alkaline phosphatase activity was measured at $72 \mathrm{~h}$ after peptide by using a kit (LSBio, USA).

\section{BMPR1A}

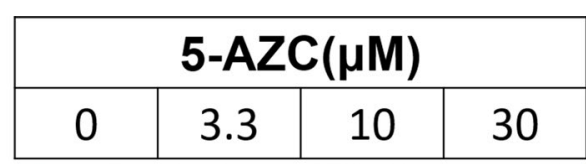

$\beta$-actin

Fig. 2 Western blot on BMPR1A in 3T3 cells. Cells were treated with indicated concentration of 5-AZC for $24 \mathrm{~h}$. B-actin was reblotted as loading control

\section{Results and Discussion}

\section{Osteoblastic Transdifferetiation of 3T3 Fibroblasts}

5AZC induced transdifferential expression of BMP receptor of BMPR1A, which transduced osteogenic signaling of BMP2, in 3 T3 cells (Ho and Bernard 2009) (Fig. 2). Plateau induction of the receptor was seen in Western blot at $24 \mathrm{~h}$ after treatment with $10 \mu \mathrm{M}$ of 5AZC. Vehicle-controlled parental 3T3 cells expressed the receptor at a marginal level. For the validation of the cell surface receptor expression, $3 \mathrm{~T} 3$ cells were stained with anti-BMPR1A antibody that was used in the WB. The FACS analysis showed cell surface expression of the receptor in the 5AZC-Tx 3T3 cells, but not in vehicle-controlled parental $3 \mathrm{~T} 3$ cells (Fig. 3).

\section{Identification of Unique Peptide Binders to 5AZC-Tx Osteoblastic 3T3 Cell Surface}

Sequence similarity of binder peptides is shown in Fig. 4. Redundant clones with high homogeneities were seen in post-DPD while pre-DPD clones showed little matching. Although whole cell panning can screen for binding of
Fig. 3 FACS analysis on cell surface BMPR1A. Cells were treated with vehicle $(\mathbf{a 1}, \mathbf{a 2})$ and $10 \mu \mathrm{M}$ of $5 \mathrm{AZC}(\mathbf{b 1}, \mathbf{b 2})$ for 24 h. Primary antibody: (a1, b1) isotype control; (a2, b2) mouse monoclonal anti-BMPR1A (4B7B2, Invitrogen, USA). Secondary antibody FITCconjugated of rabbit anti-mouse IgG (Jackson Immunoresearch, USA). X-axis: FITC; Y-axis: cell count
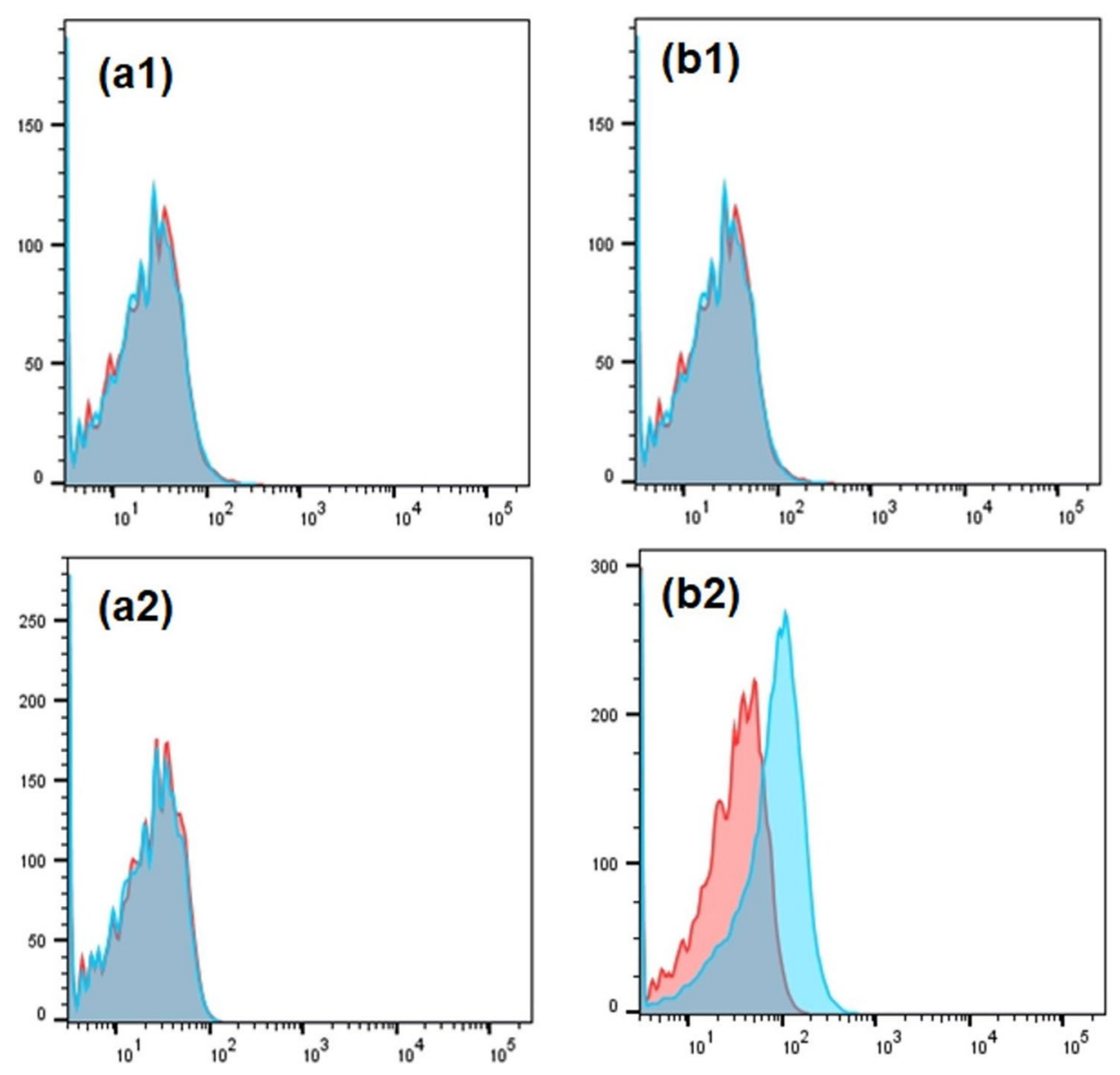


\begin{tabular}{|c|c|c|c|c|c|c|c|c|}
\hline \multicolumn{5}{|c|}{ post-dsPDP } & \multicolumn{4}{|c|}{ pre-dsDPD } \\
\hline \multicolumn{2}{|c|}{$\begin{array}{l}\text { clonal redundancy and } \\
\text { protein blast homology }\end{array}$} & $\mathbf{A L P}_{\text {mean }}$ & Std & $\begin{array}{l}p \text { to } \\
\text { ctrl }\end{array}$ & & $\mathbf{A L P}_{\text {mean }}$ & Std & $\begin{array}{l}\text { p to } \\
\text { ctrl }\end{array}$ \\
\hline & no pepitde & 0.39 & 0.03 & & & & & \\
\hline \multirow{2}{*}{$\begin{array}{c}\text { TNFRSF11A } \\
(\text { O35305/aa128-134) }\end{array}$} & $\mathbf{N} S$ & & 0.09 & $<0.01$ & L E G P $\quad$ K A W & & 0.03 & NS \\
\hline & G G & 1. & 0.11 & $<0.01$ & 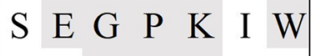 & 0.54 & 0.05 & NS \\
\hline \multirow{3}{*}{$\begin{array}{c}\text { BDNF (P21237/aa171- } \\
\text { 176) }\end{array}$} & K V P V S K L & & 0.08 & $<0.01$ & $P \quad N \quad K \quad I \quad P \quad K \quad D$ & 0.68 & 0.06 & NS \\
\hline & K V P V S K L & 1.0 & 0.12 & $<0.01$ & A $\quad \begin{array}{llllll} & S & K & I & P & M\end{array}$ & 0.48 & 0.04 & NS \\
\hline & K V P P V S K L L & 0.9 & 0.10 & $<0.01$ & K G S S A E N & 0.50 & 0.02 & NS \\
\hline \multirow{3}{*}{$\begin{array}{c}\text { no homology to mus } \\
\text { protein }\end{array}$} & 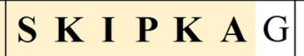 & & & $<0.01$ & $N G S G A$ E L & $0.4 \varepsilon$ & 0.02 & NS \\
\hline & $\begin{array}{lllllll}\mathbf{S} & \mathbf{K} & \mathbf{I} & \mathbf{P} & \mathbf{K} & \mathbf{A} & \mathrm{G}\end{array}$ & 1.2 & 0.16 & $<0.01$ & A Q G G Y K G & 0.39 & 0.03 & NS \\
\hline & $\begin{array}{lllllll}\mathbf{S} & \mathbf{K} & \mathbf{I} & \mathbf{P} & \mathbf{K} & \mathbf{A} & \mathrm{G} \\
\end{array}$ & 1.07 & 0.11 & $<0.01$ & A $H G$ G Y M L & 0.43 & 0.03 & NS \\
\hline \multirow{3}{*}{$\begin{array}{c}\text { Wnt10b } \\
(\text { P48614 / aa86-92) }\end{array}$} & A L R D Q R W & 0.7 & 0.1 & $<0.01$ & $\mathrm{P} H \mathrm{~A} \quad \mathrm{~T} \quad \mathrm{~K} \quad \mathrm{C} \mathrm{M}$ & 0.3 & 0.01 & NS \\
\hline & A $\mathbf{L} \mathbf{I}$ & 0.70 & 0.11 & $<0.01$ & 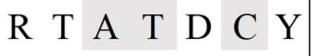 & 0.57 & 0.05 & NS \\
\hline & A L R D Q R W & & 0.06 & $<0.01$ & K Q W C I S E & & 0.03 & NS \\
\hline \multirow{3}{*}{$\begin{array}{c}\text { IGF1 } \\
\text { (p05017/aa82-88) }\end{array}$} & 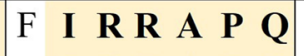 & 0.6 & 0.06 & $<0.01$ & 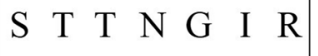 & 0.54 & 0.05 & NS \\
\hline & $\mathrm{F} \quad \mathbf{I} \quad \mathbf{R} \mathbf{R} \mathbf{A} \mathbf{P} \mathbf{Q}$ & 0.59 & 0.06 & $<0.01$ & $\mathrm{P} N \mathrm{~N}$ A A $\mathrm{S} K$ & 0.38 & 0.03 & NS \\
\hline & 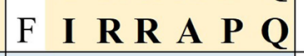 & & 0.08 & $<0.01$ & L $P$ G R Y H L & 0.44 & 0.03 & NS \\
\hline \multirow{2}{*}{$\begin{array}{c}\text { FGF2 } \\
(\mathrm{P} 15655 / \mathbf{a a 8 3}-89)\end{array}$} & & & 0.04 & $<0.05$ & $\mathrm{G} \mathrm{KV} D \mathrm{D} A \mathrm{P}$ & 0.4 & 0.02 & NS \\
\hline & A M K E D G R & 0.61 & 0.11 & $<0.01$ & $\mathrm{~L} N \mathrm{~A} Q \mathrm{E} \mathrm{D}$ & 0.52 & 0.04 & NS \\
\hline
\end{tabular}

NS: No statistically significant difference

Fig. 4 Significant enrichment of functional binders by dhDPD. Amino acid sequence was searched by BLAST against mus musculus. Sequence match to protein is pasted in yellow or blue. Mean and standard deviation (Std) of ALPase activity (OD450) were

peptides to conformational cell surface receptors, miscellaneous background proteins on plasma membrane mask the identification of target binding. Repeated rounds of panning and stringent washing can enrich high affinity bindings. However, such stringent condition may also eliminate an active, but low affinity bindings. Because of DNA hybridization-based subtraction, DPD can selectively remove common peptides of parental cell binders from treatment $\mathrm{X}$-altered cell binders. Owing to relatively long sequence of the subtraction oligo ( $38 \mathrm{nt}$; average Tm: $72{ }^{\circ} \mathrm{C}$ ), background peptide-coding sequences can be captured at a high annealing temperature of $67{ }^{\circ} \mathrm{C}$, leaving target binders in the suspension (Fig. 1). In this study, subtraction probes were prepared from tenfold higher cfu (colony forming unit) of control 3T3 cell surface binding phages (control binders) against that of 5AZC-binders. Subtraction rate can be adjusted by the cfu ratio between control binders and treatment $\mathrm{X}$-altered binders.

The present DPD used phage display of cyclic heptamer peptides. Cyclic heptamer library was selected owing to the constrained conformation of rigid structure for a future screening of therapeutic peptide candidates. Cyclic peptides tend to possess higher bioavailability and resistance to calculated from $\mathrm{n}=3$. Statistical significance to control (ctrl), $p$-value $<0.05,<0.01$, was determined by One-way ANOVA and Tukey post-hoc multi comparison test (Color figure online)

degradation by host protease (Ye et al. 2016). Linear heptamer and dodecamer peptide libraries (NEB, MA, USA) are also compatible with DPD in the same protocol.

Amino acid sequences of post-DPD clones are summarized in Fig. 4. Five clones showed homology to function: TNFRSF11A, brain-derived neurotrophic factor (BDNF) Wnt10b, insulin-like growth factor 1 (IGF1) and fibroblast growth factor-2 (FGF2). Interestingly, TNFSF11A and BDNF like peptides increased alkaline phosphatase activity in the 5AZC-Tx 3T3 cells. While osteogenic effects of Wnt3a (Almeida et al. 2009), IGF1 (Wang et al. 2017) and FGF2 (Pedersen and Febbraio 2012) have been reported, activations of ALPase by TNFRSF11A- and BDNF-like peptides were unexpected. TNFRSF11A is the well-known receptor RANK (receptor activator of NF-kappa B) that mediates osteoclastogenesis as part of a complex pathway with RANK ligand (RANKL) and osteoprotegerin (OPG), which is critical for bone metabolism and remodeling (Park et al. 2017). Although RANKL is expressed in fibroblasts (Watanabe et al. 2016), RANK is primarily a membrane receptor. However, soluble form variants naturally occur in TNFRSF receptors, such as Fas and 4-1BB (Hughes and Crispe 1995; Michel et al. 1998). It is also known that 
soluble receptors activate intracellular signaling (SmolaHess et al. 2001; Yang et al. 2007). While TNFRSF11B/ OPG, a decoy receptor of RANKL, arises from a different gene than TNFRSF11A/RANK, soluble variants of RANK might occur with some signaling function. Further studies are needed to fully elucidate the different signaling functions RANK like peptides may have, however its intrinsic nature in bone metabolism is optimistic in its potential in inducing transdifferentiation. On the other hand, osteogenic effects of BDNF was reported in bone marrow stromal cells (Liu et al. 2018; Ida-Yonemochi et al. 2017). Expression of lowaffinity nerve growth factor receptor (LNGFR), which is a known receptor of BDNF, was reported in fibroblast-like cells of bone marrow origin (Jones et al. 2002). The bindings and functions of the two peptides should be identified further in a future study. Although the other three peptides of Wnt3a-, FGF2- and IGF1-like binders showed weaker or little stimulation in alkaline phosphatase, these binders were also significant in the prediction of cell surface expressions of corresponding receptors by 5AZC treatment. All five of these binder peptides may prove to be key for inducing the transdifferentiation of fibroblasts to osteoblasts. Effective binder peptides can be identified in the next DPD between the pair of a recombinant high expression and the corresponding knockout cell lines.

While unexpected peptides were identified in DPD, BMPlike peptides were not included in the randomly picked 96-clones. Compatibility to next generation sequencing (NGS) will be a significant addition to screen out the entire binders. Since clonal identities will not be mapped in the sequencing of NGS templates in a suspension for peptide preparation in a following functional validation, automated clone picking with high throughput can expand the utility of DPD.

\section{Conclusions}

In conclusion, the present DPD showed significant potential in the screening of osteogenic peptides that bind to epigenetically induced cell surface proteins in the presence of miscellaneous background proteins in whole cell panning. This method can be a useful platform to identify therapeutic peptide candidates for inducing transdifferentiation of fibroblasts into osteoblasts for the next generation of tissue engineering.

Authors Contribution $\mathrm{WH}$ and MN contributed to the conception of this study. WH, MN, DK and SN designed the experiments. WH and MN carried out the experiments. WH wrote the manuscript. DK, HK, HK, JS, CL, SN and MN edited and revised the manuscript and coordinated the project and together wrote the manuscript.
Funding This study was supported by the Osteology Foundation Research Scholarship Project (U-16-003, Lucerne, Switzerland).

\section{Compliance with Ethical Standards}

Conflict of interest No conflicts of interest, financial or otherwise, are declared by the authors.

Open Access This article is licensed under a Creative Commons Attribution 4.0 International License, which permits use, sharing, adaptation, distribution and reproduction in any medium or format, as long as you give appropriate credit to the original author(s) and the source, provide a link to the Creative Commons licence, and indicate if changes were made. The images or other third party material in this article are included in the article's Creative Commons licence, unless indicated otherwise in a credit line to the material. If material is not included in the article's Creative Commons licence and your intended use is not permitted by statutory regulation or exceeds the permitted use, you will need to obtain permission directly from the copyright holder. To view a copy of this licence, visit http://creativecommons.org/licenses/by/4.0/.

\section{References}

Almeida M, Ambrogini E, Han L, Manolagas SC, Jilka RL (2009) Increased lipid oxidation causes oxidative stress, increased peroxisome proliferator-activated receptor-gamma expression, and diminished pro-osteogenic Wnt signaling in the skeleton. J Biol Chem 284(40):27438-27448. https://www.jbc.org/conte $\mathrm{nt} / 284 / 40 / 27438$

Banwart JC, Asher MA, Hassanein RS (1995) Iliac crest bone graft harvest donor site morbidity. A statistical evaluation. Spine 20(9):1055-1060. https://journals.lww.com/spinejournal/Abstr act/1995/05000/Iliac_Crest_Bone_Graft_Harvest_Donor_Site.12. aspx

Canady JW, Zeitler DP, Thompson SA, Nicholas CD (1993) Suitability of the iliac crest as a site for harvest of autogenous bone grafts. Cleft Palate Craniofac J Off Publ Am Cleft PalateCraniofac Assoc 30(6):579-581. https://doi.org/10.1597/15451569_1993_030_0579_sotica_2.3.co_2

Cho Y, Kim B, Bae H, Kim W, Baek J, Woo K, Lee G, Seol Y, Lee Y, Ku Y, Rhyu I, Ryoo H (2017) Direct gingival fibroblast/osteoblast transdifferentiation via epigenetics. J Dental Res 96(5):555-561. https://doi.org/10.1177/0022034516686745

deGruyter JN, Malins LR, Baran PS (2017) Residue-specific peptide modification: a chemist's guide. Biochemistry 56(30):3863-3873. https://doi.org/10.1021/acs.biochem.7b00536

Giannoudis PV, Dinopoulos H (2005) Bone substitutes: an update. Injury 36(Suppl 3):S20-S27. https://www.sciencedirect.com/scien ce/article/abs/pii/S0020138305002871?via\%3Dihub

Ho CC, Bernard DJ (2009) Bone morphogenetic protein 2 signals via BMPR1A to regulate murine follicle-stimulating hormone beta subunit transcription. Biol Reprod 81(1):133-141. https://acade mic.oup.com/biolreprod/article/81/1/133/2557868

Hughes DP, Crispe IN (1995) A naturally occurring soluble isoform of murine Fas generated by alternative splicing. J Exp Med 182(5):1395-1401. https://rupress.org/jem/artic le/182/5/1395/25745/A-naturally-occurring-soluble-isoform-ofmurine

Ida-Yonemochi H, Yamada Y, Yoshikawa H, Seo K (2017) Locally produced BDNF promotes sclerotic change in alveolar bone after nerve injury. PLoS ONE 12(1):e0169201. https://doi.org/10.1371/ journal.pone.0169201 
Jones EA, Kinsey SE, English A, Jones RA, Straszynski L, Meredith DM, Markham AF, Jack A, Emery P, McGonagle D (2002) Isolation and characterization of bone marrow multipotential mesenchymal progenitor cells. Arthritis Rheum 46(12):3349-3360. https ://doi.org/10.1002/art.10696

Kalk WW, Raghoebar GM, Jansma J, Boering G (1996) Morbidity from iliac crest bone harvesting. J Oral Maxillofac Surg 54(12):1424-1429. https://www.sciencedirect.com/science/artic le/pii/S0278239196902578?via\%3Dihub

Liang P, Pardee AB (1992) Differential display of eukaryotic messenger RNA by means of the polymerase chain reaction. Science 257(5072): 967-971. https://science.sciencemag.org/conte nt/257/5072/967

Liu Q, Lei L, Yu T, Jiang T, Kang Y (2018) Effect of brain-derived neurotrophic factor on the neurogenesis and osteogenesis in bone engineering. Tissue Eng Part A 24(15-16):1283-1292. https:// doi.org/10.1089/ten.tea.2017.0462

Ma L, Zhou Y, Zhu Y, Lin Z, Chen L, Zhang Y, Xia H, Mao C (2017) 3D printed personalized titanium plates improve clinical outcome in microwave ablation of bone tumors around the knee. Sci Rep 7(1):7626. https://www.nature.com/articles/s41598-017-07243-3

Michel J, Langstein J, Hofstädter F, Schwarz H (1998) A soluble form of CD137 (ILA/4-1BB), a member of the TNF receptor family, is released by activated lymphocytes and is detectable in sera of patients with rheumatoid arthritis. Eur J Immunol 28(1):290-295. https://doi.org/10.1002/\%28SICI\%29152 1-4141\%28199801\%2928\%3A01\%3C290\%3A\%3AAID-IMMU2 90\%3E3.0.CO\%3B2-S

Myeroff C, Archdeacon M (2011) Autogenous bone graft: donor sites and techniques. J Bone Joint Surg 93(23):2227-2236. https://journ als.1ww.com/jbjsjournal/Fulltext/2011/12070/Ankle_Dorsiflexo r_Function_After_Plantar_Flexor.13.aspx

Park JH, Lee NK, Lee SY (2017) Current understanding of RANK signaling in osteoclast differentiation and maturation. Mol Cells 40(10):706-713. https://doi.org/10.14348/molcells.2017.0225

Pedersen BK, Febbraio MA (2012) Muscles, exercise and obesity: skeletal muscle as a secretory organ. Nat Rev Endocrinol 8(8):457465. https://www.nature.com/articles/nrendo.2012.49
Salgado AJ, Coutinho OP, Reis RL (2004) Bone tissue engineering: state of the art and future trends. Macromol Biosci 4(8):743-765. https://doi.org/10.1002/mabi.200400026

Schmidmaier G, Schwabe P, Wildemann B, Haas NP (2007) Use of bone morphogenetic proteins for treatment of non-unions and future perspectives. Injury 38(Suppl 4):S35-S41. https://www. sciencedirect.com/science/article/abs/pii/S00201383087000 $7 X$ ?via\%3Dihub

Smola-Hess S, de Silva US, Hadaschik D, Pfister HJ (2001) Soluble interleukin-6 receptor activates the human papillomavirus type 18 long control region in SW756 cervical carcinoma cells in a STAT3-dependent manner. J Gen Virol 82(Pt 10):2335-2339. https://doi.org/10.1099/0022-1317-82-10-2335

Tannoury CA, An HS (2014) Complications with the use of bone morphogenetic protein 2 (BMP-2) in spine surgery. Spine J 14(3):552559. https://www.sciencedirect.com/science/article/abs/pii/S1529 943013019840?via\%3Dihub

Ueki N, Someya K, Matsuo Y, Wakamatsu K, Mukai H (2007) Cryptides: functional cryptic peptides hidden in protein structures. Biopolymers 88(2):190-198. https://doi.org/10.1002/bip.20687

Wang T, Zhang X, Bikle DD (2017) Osteogenic differentiation of periosteal cells during fracture healing. J Cell Physiol 232(5):913921. https://doi.org/10.1002/jcp.25641

Watanabe T, Takahashi N, Hirabara S, Ishiguro N, Kojima T (2016) Hyaluronan inhibits Tlr-4-dependent RANKL expression in human rheumatoid arthritis synovial fibroblasts. PLoS ONE 11(4):e0153142. https://doi.org/10.1371/journal.pone.0153142

Yang J, Runeberg-Roos P, Leppänen VM, Saarma M (2007) The mouse soluble GFRalpha4 receptor activates RET independently of its ligand persephin. Oncogene 26(26):3892-3898. https://www.natur e.com/articles/1210161

Ye F, Li J, Yang CG (2016) The development of small-molecule modulators for ClpP protease activity. Mol Biosyst 13(1):23-31. https ://pubs.rsc.org/en/content/articlelanding/2017/MB/C6MB00644B \#!divAbstract

Publisher's Note Springer Nature remains neutral with regard to jurisdictional claims in published maps and institutional affiliations. 


\title{
Affiliations
}

\section{Wataru Hatakeyama ${ }^{1,2} \cdot$ Cliff Lee $^{1} \cdot$ John Da Silva ${ }^{3} \cdot$ David M. Kim $^{1} \cdot$ Shigemi Nagai $^{1} \cdot$ Hisatomo Kondo $^{2}$. Masazumi Nagai ${ }^{1}$ (1)}

\author{
Masazumi Nagai \\ Masazumi_Nagai@hms.harvard.edu \\ Wataru Hatakeyama \\ whatake@iwate-med.ac.jp \\ Cliff Lee \\ Cliff_Lee@hsdm.harvard.edu \\ John Da Silva \\ john_dasilva@hsdm.harvard.edu \\ David M. Kim \\ dkim@hsdm.harvard.edu \\ Shigemi Nagai \\ shigemi_nagai@hsdm.harvard.edu
}

Hisatomo Kondo

hisakondo@gmail.com

1 Division of Periodontology, Department of Oral Medicine, Infection, and Immunity, Harvard School of Dental Medicine, 188 Longwood Avenue, Boston, MA 02115, USA

2 Department of Prosthodontics and Oral Implantology, School of Dentistry, Iwate Medical University, 19-1 Uchimaru, Morioka, Iwate 020-8505, Japan

3 Department of Restorative Dentistry and Biomaterials Sciences, Harvard School of Dental Medicine, 188 Longwood Avenue, Boston, MA 02115, USA 